\title{
Activation of Sterol-Responsive Element Binding Proteins in a Sucrose- Induced Model of Lysosomal Storage
}

\author{
Guillaume Van Beersel ${ }^{1}$, Michel Jadot ${ }^{2}$, Isabelle Hamer² and Thierry Arnould ${ }^{*}, 1$ \\ ${ }^{1}$ Laboratory of Biochemistry and Cellular Biology (URBC), ${ }^{2}$ Laboratory of Physiological Chemistry (URPhyM), NAmur \\ Research Institute for LIfe Sciences (NARILIS), University of Namur, Rue de Bruxelles, 61, B-5000 Namur, Belgium
}

\begin{abstract}
The accumulation of pinocytosed sucrose in lysosomes constitutes a convenient means to mimic a lysosomal storage and to study how such storage impacts the biology of the organelle and beyond. Several reports have shown that lysosomal storages can perturb the redistribution of lysosomal lipids, cholesterol in particular. Our goal was to analyse the effect of the intralysosomal accumulation of sucrose on the transcription factors Sterol Regulatory Element Binding Proteins (SREBPs): key actors of the regulation of lipid metabolism. We show that 143B cells grown in the presence of sucrose present a modified distribution of non-esterified cholesterol, which is associated with an increase in the activity of SREBPs. The activation of these transcription factors is associated with an increase in the expression of some of their target genes: HMG-CoA synthase and mevalonate kinase, and with an increase in total lipid biosynthesis. Finally, using siRNA interference we demonstrate that SREBP-2 but not SREBP-1a is responsible for the increase in the expression of the genes encoding these two enzymes.
\end{abstract}

Keywords: Cholesterol, lysosome, SREBPs, sucrose.

\section{INTRODUCTION}

The Lysosomal Storage Diseases (LSDs) result from an impaired processing of the material sequestrated in lysosomes during endocytosis or autophagy. The more than 50 LSDs currently described are usually inherited as autosomal recessive traits and can result from defects in lysosomal hydrolases, in non-enzymatic lysosomal proteins or even in non-lysosomal proteins that alter lysosomal functions [1].

The molecular mechanisms by which the lysosomal storage triggers cell dysfunction (and eventually cell death) have been the subject of extensive research during the last decade (reviewed in [2,3]). They involve accumulation of secondary metabolites [4], ER stress [5], alteration of calcium homeostasis [6] and autophagy [7], generation of oxidative stress [8] but also perturbation of the lipid homeostasis (reviewed in [2]).

Sterol Regulatory Element Binding Proteins (SREBPs) are key actors of the molecular regulation of lipid metabolism. SREBPs are synthesized as precursors and threaded into the ER membrane. When the cellular supply of lipids is limiting, these proteins are translocated to the Golgi apparatus and cleaved through sequential actions of two membrane-bound proteases thereby releasing the soluble amino-terminal mature SREBP that can, in turn, activate the expression of genes encoding proteins required for lipid biosynthesis [9]. The SREBP family entails three members encoded by two genes: SREBP-1c, SREBP-1a and SREBP2. SREBP-1a and SREBP-1c are produced through the

*Address correspondence to this author at the University of Namur, University of Namur, (FUNDP), rue de Bruxelles, 61, 5000 Namur, Belgium;

Fax: +32-81-724135; E-mail: thierry.arnould@fundp.ac.be alternative splicing of the exons $1 \mathrm{a}$ and $1 \mathrm{c}$ of the gene $S R E B F 1$, while the SREBP-2 isoform is the product of the gene SREBF2 [10]. Previous studies using transgenic mice that overexpress one of the SREBP isoforms suggested that both proteins encoded by the SREBF1 gene, SREBP-1a and SREBP-1c, preferentially target genes encoding enzymes involved in the fatty acid metabolism whereas SREBP-2 preferentially activates the expression of genes of cholesterol metabolism [11-13].

Even if skin fibroblasts derived from LSDs patients constitute a widely used experimental model for the study of the LSDs ([14, 15], a lysosomal storage can also be triggered experimentally by adding sucrose to the cell culture medium. Pinocytic uptake of the disaccharide will lead to its gross accumulation in invertase devoid lysosomes [16], mimicking a "lysosomal storage phenotype" [17, 18]. Such sucroseinduced lysosomal storage has been shown to have numerous detrimental effects on the endo-lysosomal system by, for example, impairing the vesicular transport trafficking that exists between the endosomes and lysosomes [19, 20] and perturbing the biosynthetic maturation of several lysosomal hydrolases [21, 22]. Besides this defect in trafficking, the team of Karageorgos showed that the storage of sucrose in lysosomes led to an increased population of this organelle and to the over-expression of several genes encoding lysosomal proteins [17]. Interestingly, similar defect in the cathepsin B maturation [21] as well as an increase in lysosomal biogenesis [17] have been reported in skin fibroblasts derived from LSDs patients, suggesting that the lysosomal storage of sucrose is able to trigger cellular responses found in naturally occurring lysosome overloads. Another advantage of the sucrose model is the possibility it offers to study the putative transitory molecular events occurring at the setting up of the organelle overload. Finally, 
the ease with which the storage can be prevented or reversed by incubating the cells in the presence of exogenously added invertase represents a convenient means to assess the causative effect of the storage itself in the various cellular responses triggered by the addition of sucrose in the medium.

In this study, we analyzed the effect of a sucrose-induced lysosomal storage on the intracellular cholesterol distribution and the activity of SREBPs. We show that the non-esterified cholesterol distribution is modified in 143B cells incubated with sucrose. We demonstrate that this aberrant free cholesterol distribution is associated with an increase in the activity of SREBPs. Moreover, we show that the activation of these transcription factors is associated with an increase in the expression of HMG-CoA synthase and mevalonate kinase, the products of two of their target genes, and with an increase in total lipid biosynthesis. Finally, using siRNA interference we demonstrate that SREBP-2 but not SREBP$1 \mathrm{a}$ is responsible for the expression of the genes encoding these two enzymes.

\section{MATERIAL AND METHODOLOGY}

\subsection{Cell Cultures}

The 143B cell line (human bone osteosarcoma cells) was kindly provided by Professor G. Attardi (Caltech, Pasadena, CA, USA). 143B cells (chosen as they have numerous lysosomes and high expression level of cathepsin B in response to mt-DNA-depletion [23]) were grown in DMEM (Dulbeccos's Modified Eagle's medium) high glucose supplemented with $10 \%$ (v/v) fetal calf serum). At confluence, cells were trypsinised using $0.25 \%$ trypsinEDTA (Gibco) and subcultured in 24-well, 12-well or 6-well plates or $25 \mathrm{~cm}^{2}$ culture flasks, according to the experimental needs or $75 \mathrm{~cm}^{2}$ culture flasks (Corning) for maintaining the cells in culture. For the different experiments, $8 \mathrm{~h}$ later, the medium was removed and cells were pre-incubated (IS) or not with $100 \mu \mathrm{g} / \mathrm{ml}$ invertase (I-4504, Sigma). Following 16 $\mathrm{h}$ of incubation, cells were incubated ( $\mathrm{S}$ or IS) or not (CTL) with $100 \mathrm{mM}$ sucrose during the indicated times.

\subsection{Self-Formed Percoll Density Gradients}

Self-formed percoll density gradients were performed as previously described [22]. The $\beta$-galactosidase and $\beta$ hexosaminidase enzymatic activities were assayed in each fraction as described previously [24].

\subsection{Filipin Staining}

143B cells were seeded onto glass coverslips (VWR) in 24-well culture plates (Corning). At the end of the incubation with sucrose, cells were fixed for $10 \mathrm{~min}$ with $4 \%$ paraformaldehyde, permeabilized for $5 \mathrm{~min}$ with $\mathrm{PBS} / 1 \%$ Triton X-100, and then incubated for $2 \mathrm{~h}$ with $500 \mu \mathrm{g} / \mu \mathrm{l}$ filipin (F-4767, Sigma) diluted in PBS at room temperature and processed for epifluorescence.

\subsection{Transient Transfection and Luciferase Reporter Gene Assay}

143B cells were seeded in 12-well plates and $5 \mathrm{~h}$ later, cells were transiently co-transfected using the Superfect reagent (Qiagen) for $3 \mathrm{~h}$ at a 1:5 ratio, with a luciferase reporter construct $(0.75 \mu \mathrm{g} / \mathrm{well})$ together with an expression plasmid encoding Escherichia coli $\beta$-galactosidase $(0.25$ $\mu \mathrm{g} /$ well) under the control of a CMV promoter (pCMVLacZ; PlasmidFactory). We used different constructs in which the expression of the luciferase gene was respectively driven by either the authentic promoter of the human low density lipoprotein receptor (LDLr), 3-hydroxy-3methylglutaryl-coenzyme A (HMG-CoA) synthase, stearoylCoA desaturase-2 (SCD-2) (kindly offered by the P. J-B. Demoulin, Faculté de Pharmacie et des Sciences Biomédicales (FASB) Université Catholique de Louvain, Belgium). At the end of this incubation, the medium was removed and cells were pre-incubated or not with $100 \mu \mathrm{g} / \mathrm{ml}$ invertase. After $16 \mathrm{~h}$ of incubation, cell were incubated ( $\mathrm{S}$ or IS) or not (CTL) for $24 \mathrm{~h}$ with $100 \mathrm{mM}$ sucrose. At $36 \mathrm{~h}$ post-transfection, cells were lysed and the luciferase activity was determined using a luciferase reporter assay (Promega) as previously described [23].

\subsection{Gene Expression and Real Time RT-qPCR}

Total RNA was extracted from 143B cells using the QIAGEN RNeasy mini kit and the QIAcube machine (QIAGEN, USA) according to the manufacturer's instructions. One microgram of total RNA was reverse transcribed in cDNA using the Transcriptor first strand cDNA synthesis kit (Roche, USA). Specific primers for the HMG-CoA synthase, the LDLr, the Fatty Acid Synthase (FASN), Stearoyl-CoA Synthase 1 (SCD-1), mevalonate Kinase (MVK) and aldolase were designed using the Primer Express 1.5 software (Applied Biosystems). Real-time PCR was performed with the Abi-Prism 7000 Sequence Detection System (Applied Biosystems) and the data were subjected to relative quantification using gene encoding aldolase as endogenous reference gene for normalization. The $\Delta \Delta \mathrm{Ct}$ method was used to each sample in order to calculate the relative fold induction. Data calculation and normalization were performed according to de Longueville et al. [25].

\subsection{Preparation of Clear Cell and Nuclear Lysates and Western Blot Analyses}

The clear cell lysates were prepared as previously described [26]. For the preparation of clear nuclear lysates, $143 \mathrm{~B}$ cells were seeded in $75 \mathrm{~cm}^{2}$ culture flasks. Following the sucrose treatment, cells were washed thrice with ice-cold PBS and incubated with a hypotonic buffer $(20 \mathrm{mM}$ Hepes; $\mathrm{pH}$ 7.9, $50 \mathrm{mM}$ sodium fluoride, $1 \mathrm{mM}$ sodium molybdate, 1 $\mathrm{mM}$ EDTA). After $5 \mathrm{~min}$, cells were scraped from the culture flasks and incubated for $5 \mathrm{~min}$ in $500 \mu \mathrm{l}$ of lysis buffer (10 mM Tris- $\mathrm{HCl}$; $\mathrm{pH} 7.4,3 \mathrm{mM}$ magnesium chloride, $10 \mathrm{mM}$ sodium chloride, and $0.5 \%$ Nonidet P-40). Finally, the nuclei were separated from the cytosol by brief centrifugation and resuspended in RIPA (Radioimmunoprecipitation Assay) buffer (50 mM Tris-HCl; pH 7.4, $1 \%$ Nonidet P-40, $0.25 \%$ sodium deoxycholate, $150 \mathrm{mM}$ sodium chloride, $1 \mathrm{mM}$ EDTA, $1 \mathrm{mM}$ sodium fluoride, 1 $\mathrm{mM}$ sodium orthovanadate, and a protease inhibitor cocktail (cOmplete, Roche Applied Science). After incubation on ice for $30 \mathrm{~min}$, cell lysates were centrifuged for $10 \mathrm{~min}$ at 13,000 RPM $\left(4^{\circ} \mathrm{C}\right)$ and the supernatants were collected (clear nuclear lysates). Protein concentration was determined using the Pierce $660 \mathrm{~nm}$ Protein Assay kit (Thermo Scientific). 
Amounts corresponding to $40 \mu \mathrm{g}$ of total proteins were resolved on $3-8 \%$ or $12 \%$ bis-Tris gels (NuPage, Invitrogen). Western blot analysis was performed as previously described [27] with primary antibodies against either human SREBP-1 (\# 557036 concentration: $0.1 \mu \mathrm{g} / \mathrm{ml}$, Pharmingen), human SREBP-2 (\# 557037, concentration: $0.1 \mu \mathrm{g} / \mathrm{ml}$, Pharmingen) human SCD-1 (SC-81776, concentration: $0.2 \mu \mathrm{g} / \mathrm{ml}$, Santa Cruz Biotechnology), human FASN (C20G5, concentration: $0.1 \mu \mathrm{g} / \mathrm{ml}$, Cell Signaling) human mevalonate kinase (ab90888, concentration: $1 \mu \mathrm{g} / \mathrm{ml}$, Abcam) or HMG-CoA synthase (ab87246, concentration: 1 $\mu \mathrm{g} / \mathrm{ml}$, Abcam), human LDLr (ab134998, concentration: 1 $\mu \mathrm{g} / \mathrm{ml}$ Abcam) incubated for $16 \mathrm{~h}$ at $4^{\circ} \mathrm{C}$. Western Blot analysis was performed either by chemiluminescence (ECL advanced, Amersham Biosciences) in the case of SREBP-1 and SREBP-2 or by infrared fluorescence (Odyssey Scanner, Li-Cor). For ECL detection, a horseradish peroxidaseconjugated antibody (Amersham Biosciences) was used as a secondary antibody at a concentration of $0.01 \mu \mathrm{g} / \mathrm{ml}$. For the Western Blot in fluorescence, a secondary antibody coupled to infrared dyes (Li-Cor) was used at a concentration of 0.02 $\mu \mathrm{g} / \mathrm{ml}$. The correct protein loading was determined by the immuno-detection of either the $\alpha$-tubulin for the clear cell lysates or of the Lamin B (SC-6216, concentration: 0.04 $\mu \mathrm{g} / \mathrm{ml}$, Santa Cruz Biotechnology) for the nuclear lysates.

\subsection{Silencing of SREBP-1 and SREBP-2 Expression and SIRNA}

siRNA transfection experiments were performed using double stranded RNA (SMARTpool, Dharmacon). ONTARGET plus non-targeting pool was used as a control. 143B cells were transfected with $25 \mathrm{nM}$ siRNA for SREBP1 (\# L-006891-00, Dharmacon) or SREBP-2 (\# L-00954900) and with the DharmaFECT1 transfection reagent (Dharmacon, T-2001, Lafayette USA) according to the manufacturer's instructions. Silencing was checked $24 \mathrm{~h}$ post-transfection by reverse transcription of total extracted RNA followed by real time RT-qPCR. For Western Blotting analysis, cells were lysed $24 \mathrm{~h}$ post-transfection in lysis buffer (7 M urea, $2 \mathrm{M}$ thiourea, $\mathrm{pH} 8.5$, CHAPS $4 \%$ (v/v), $60 \mathrm{mM}$ dithiotreitol, $1 \mathrm{mM}$ sodium orthovanadate, $10 \mathrm{mM}$ para-nitrophenylphosphate, $10 \mathrm{mM} \beta$-glycero-phosphate, 5 $\mathrm{mM}$ sodium fluoride and protease inhibitor cocktail (Roche Applied Science))

\subsection{Incorporation of $\left[{ }^{3} \mathbf{H}\right]$ Acetate into Cholesterol and Fatty Acids}

143B cells were seeded in 6-well plates (Corning). During the $24 \mathrm{~h}$ last hours of the incubation with $100 \mathrm{mM}$ sucrose, $\left[{ }^{3} \mathrm{H}\right]$-acetate $(2 \mu \mathrm{Ci}$, Perkin Elmer) was added to the culture medium to monitor the cellular synthesis of cholesterol and fatty acids. The assessment of $\left[{ }^{3} \mathrm{H}\right]$-labelled total cholesterol (including free cholesterol and cholesterol moiety in cholesterol esters) and $\left[{ }^{3} \mathrm{H}\right]$-labelled fatty acids was conducted according to the protocol of Bligh and Dyer [28]. Lipids were extracted and lipid radioactivity was counted in an aliquot with a scintillation fluid (Lipoluma; Lumac). The results were normalized by total protein content determined by the BCA (bicinchoninic acid) kit (Pierce).

\section{RESULTS}

\subsection{The Sucrose Model}

Lysosomal storage was generated by 143B cell incubation in the presence of $100 \mathrm{mM}$ sucrose. When the ultrastructure of the cells is analysed by electron transmission microscopy, horseradish peroxidase (HRP)loaded and containing lysosomes in control cells appear as electron dense spherical vesicles. However, in sucrosetreated cells, lysosomes display heterogeneous and dilated forms and sizes and contain heterogeneous material (and some residual HRP) (data not shown). As a control, 143B cells were pre-incubated for $16 \mathrm{~h}$ with $100 \mu \mathrm{g} / \mathrm{ml}$ invertase, a hydrolase active in lysosomes after its endocytosis, catalysing the breakdown of sucrose into two membrane permeable monosaccharides, thereby preventing the accumulation of sucrose [16]. In order to assess the extent of the storage through its impact on the organelle density, the sedimentable fraction of a post nuclear supernatant prepared from $143 \mathrm{~B}$ cells incubated for $48 \mathrm{~h}$ with $100 \mathrm{mM}$ sucrose was analyzed by isopycnic centrifugation on a self-formed isotonic percoll density gradient. As seen in Fig. (1), incubation of the cells with sucrose induced a decrease in the density of lysosomes as shown by the shift of the distribution of the marker enzymes, $\beta$-galactosidase and $\beta$ hexosaminidase, from the high to the low-density zone of the gradient. Such a decrease in the density of the lysosomes could be prevented when cells were pre-incubated for $16 \mathrm{~h}$ with $100 \mu \mathrm{g} / \mathrm{ml}$ of invertase. Similar results have been obtained with HepG2 cells (data not shown).

\subsection{B Cells Incubated with Sucrose Show an Aberrant Intracellular Distribution of Non-Esterified Cholesterol}

Accumulation of free cholesterol inside the endosomes and the lysosomes has been frequently observed in various LSDs [29-31]. We used filipin in order to determine the putative effect of a sucrose-induced lysosomal storage on the intracellular cholesterol distribution of 143B cells. Fig. (2) shows that the filipin staining observed in 143B cells incubated for $48 \mathrm{~h}$ with sucrose was more intense and concentrated in vesicular structures. This peculiar staining was no longer observed in 143B cells pre-incubated with invertase (Fig. 2).

\subsection{SREBP Target Genes are Activated in 143B Cells Incubated with Sucrose}

The observation of a modified distribution of cholesterol in cells incubated with $100 \mathrm{mM}$ sucrose, prompted us to analyze the activity of the SREBP transcription factors in response to the intra-lysosomal storage of sucrose. To this aim, cells were transiently transfected with luciferase reporter constructs under the control of the authentic promoters of three SREBP target genes, encoding the LDL receptor, the HMG-CoA synthase and the stearoyl-CoA desaturase-2, respectively. Fig. (3A) shows that the activities of these reporters were significantly increased in 143B cells incubated with sucrose. Importantly, pre-incubation for $16 \mathrm{~h}$ with invertase significantly prevented the observed 
activation for the HMG-CoA synthase and SCD-2 reporters demonstrating that the SREBP-mediated transcriptional activation is the consequence of the lysosomal storage of sucrose. In this set of experiments, the prevention of the LDLr reporter activation by invertase could also be obtained but did not reach statistical significance (Fig. 3A). Similar results were obtained in HepG2 cells (data not shown).

\section{$\beta$-galactosidase}

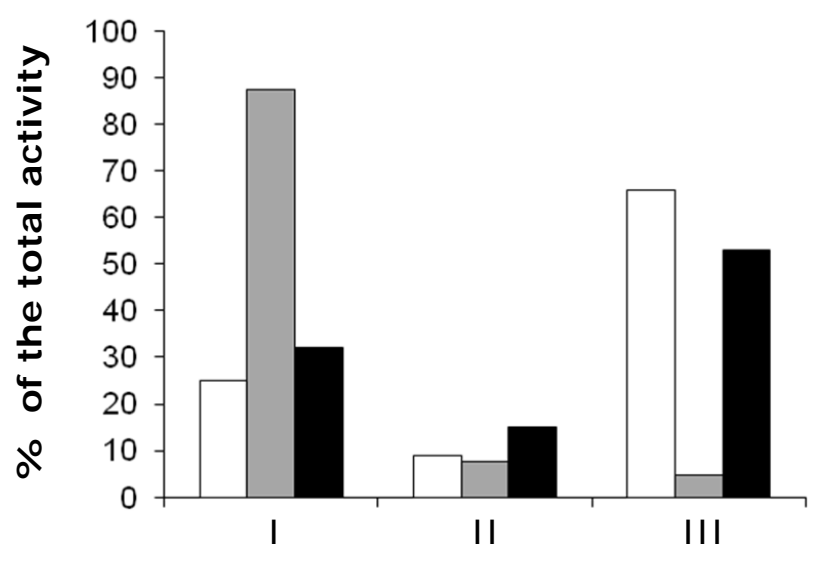

$\beta$-hexosaminidase

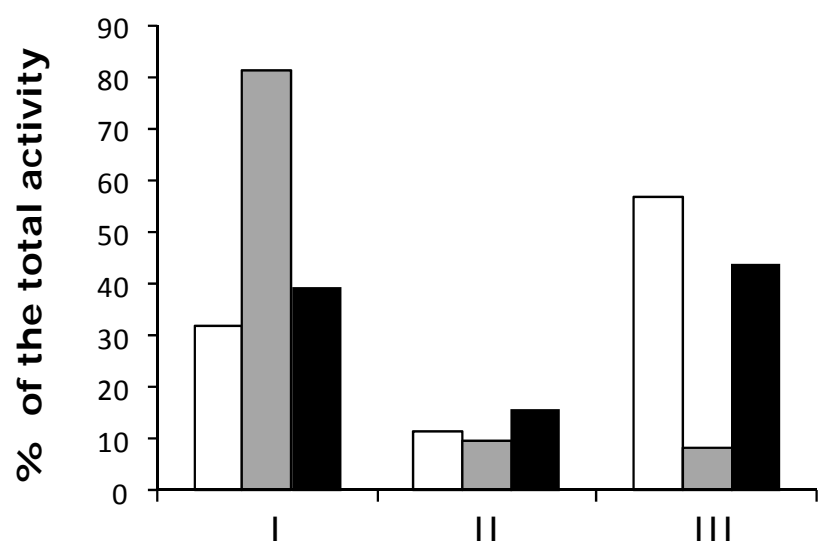

Fig. (1). Effect of lysosomal sucrose storage on the density of the lysosomes. $\beta$-galactosidase and $\beta$-hexosaminidase activities distribution in self-formed Percoll density gradients. MLP fractions were prepared from 143B cells incubated for $48 \mathrm{~h}$ with or without $100 \mathrm{mM}$ sucrose (respectively dark grey and white columns). Cells first pre-incubated for $16 \mathrm{~h}$ with $100 \mu \mathrm{g} / \mathrm{ml}$ invertase and then with sucrose were used as controls (black columns). Briefly the MLP fractions, prepared by differential centrifugation, were fractioned on an isotonic Percoll density gradient as described in the Material and Methods section. Ten fractions were collected from the top to the bottom of the gradient and enzymatic activities were assayed by fluorescence. The pools I, II and III correspond to the fractions 1-4, 5-8 and 9-10, respectively. Results were calculated as arbitrary fluorescence units and are expressed in percentages of the total activity found in each gradient.

Next, we monitored by Western blotting the nuclear abundance of SREBP-2. As a positive control, 143B cells were incubated for $24 \mathrm{~h}$ in lipid-depleted medium (without serum) a condition that is known to trigger the nuclear translocation of this transcription factor [32]. Moreover, knowing that the nuclear form of SREBP-2 is rapidly degraded by the ubiquitin proteasome pathway [33], MG132, a well-known proteasome inhibitor, was added for $5 \mathrm{~h}$. As expected, the nuclear amount of SREBP-2 was increased in these conditions (Fig. 3B). But more interestingly, it was also significantly increased in 143B cells incubated for $24 \mathrm{~h}$ with sucrose (Fig. 3B, C). This increase in the abundance of SREBP-2 is no longer observed in cells that had been preincubated with invertase, showing that the increased transcriptional activity is correlated with an increased abundance of SREBP-2 in the nuclei of sucrose-treated cells.
CTL
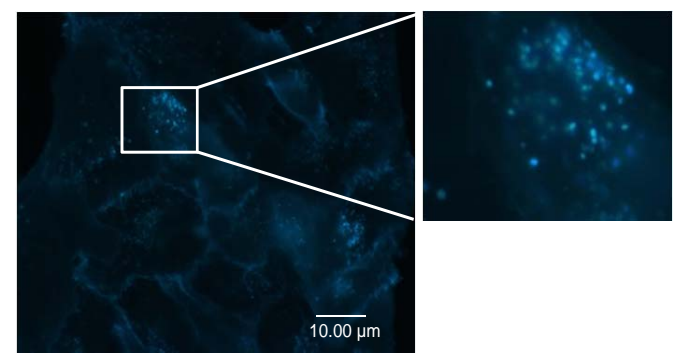

$\mathbf{S}$
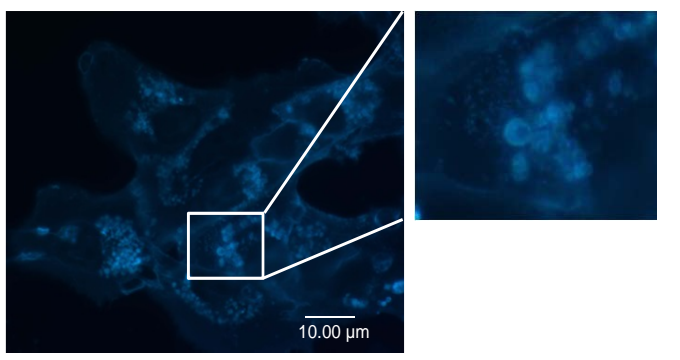

I/S
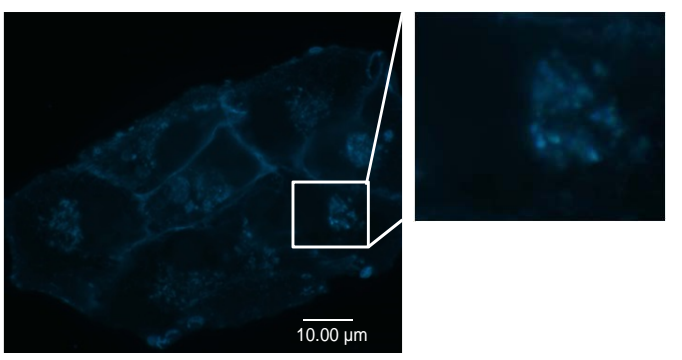

Fig. (2). Effect of lysosomal sucrose storage on the distribution of the non-esterified cholesterol. Representative epifluorescence images of the non-esterified cholesterol distribution in 143B cells incubated for $48 \mathrm{~h}$ in absence (CTL) or in presence of $100 \mathrm{mM}$ sucrose (S and IS) and stained with $0.5 \mathrm{mg} / \mathrm{ml}$ filipin. In (I/S), cells were first pre-incubated for $16 \mathrm{~h}$ with $100 \mu \mathrm{g} / \mathrm{ml}$ invertase. Right upper panels show magnified details of selected areas (boxes) in the left panels. Scale bars represent $10 \mu \mathrm{m}$.

\subsection{Expression of Several Genes Involved in Cholesterol and Fatty Acid Biosynthesis are Increased in 143B Cells Incubated with $100 \mathrm{mM}$ Sucrose}

SREBP activated gene products predominantly belong to lipid metabolism pathways including fatty acid and phospholipid synthesis and cholesterogenesis [34]. Our first results suggesting that the transcription factors SREBPs are activated in 143B cells incubated with sucrose, we analyzed the transcriptional expression of HMG-CoA synthase, LDLr, fatty acid synthase, SCD-1 and mevalonate kinase in cells incubated for $48 \mathrm{~h}$ with $100 \mathrm{mM}$ sucrose. As seen in Fig. 
A
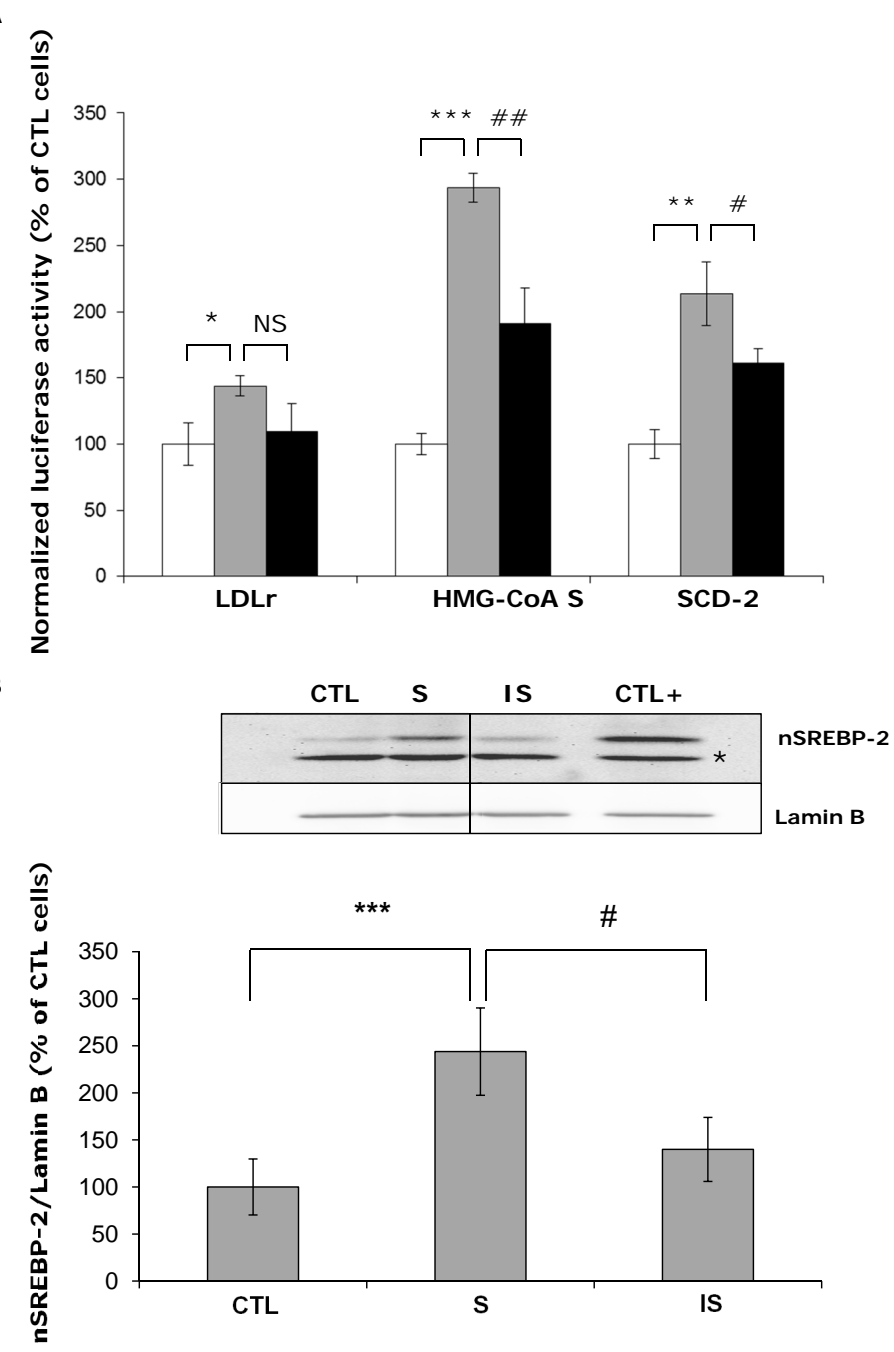

Fig. (3). Effect of a lysosomal sucrose storage on SREBPs activity. (A) 143B cells incubated for $24 \mathrm{~h}$ with (grey and black columns) or without (white columns) $100 \mathrm{mM}$ sucrose were transiently co-transfected with a reporter plasmid in which the expression of the luciferase gene was controlled by the authentic promoter of the LDLr, HMG-CoA synthase or SCD-2 along with the pCMV-lacZ plasmid for normalization. Cells first pre-incubated for $16 \mathrm{~h}$ with $100 \mu \mathrm{g} / \mathrm{ml}$ invertase were used as controls (black columns). The activities of both luciferase and $\beta$-galactosidase were determined $36 \mathrm{~h}$ after transfection on cell lysates as described in the Material and Methods section. Results are expressed in percentages of the activity found in CTL cells as means \pm SD $(\mathrm{n}=3)^{* * *}$, **, *: Significantly different from CTL cells with respectively $\mathrm{P}<0.001, \mathrm{P}<0.01$ or $\mathrm{P}<0.05$. \#, \#\#: Significantly different from $143 \mathrm{~B}$ cells incubated with sucrose with $\mathrm{P}<0.05$ and $\mathrm{P}<0.01$, respectively, as determined by an ANOVA-1 followed by a Dunnett's test. NS: non significantly different from 143B cells incubated with sucrose. (B) The nuclear abundance of SREBP-2 was analyzed by Western Blotting performed on $40 \mu \mathrm{g}$ of proteins from clear nuclear lysates proteins prepared from 143B cells incubated for $24 \mathrm{~h}$ with (S), (IS) or without (CTL) $100 \mathrm{mM}$ sucrose. In (IS), cells were first preincubated for $16 \mathrm{~h}$ with $100 \mu \mathrm{g} / \mathrm{ml}$ invertase. Equal protein loading was controlled by the immuno-detection of the lamin B. As positive control (CTL +), DMEM without serum and for $5 \mathrm{~h}$ with $10 \mu \mathrm{M}$ of the cell-permeable proteasome inhibitor MG-132. The asterisk denotes a nonspecific and uncharacterized band. (C) Quantification of the nuclear abundance of SREBP-2. Results are calculated as O.D. normalized for lamin B, expressed in percentages of CTL cells and represent means \pm SD $(n=3) * * *$ : Significantly different from CTL cells with $\mathrm{P}<0.001$, \#: Significantly different from 143B cells incubated with sucrose with $\mathrm{P}<0.05$ as determined by an ANOVA-1 followed by a Dunnett's test. For a clearer presentation, one nonessential condition in which cells have been incubated with the invertase alone has been sliced from the original blot. Band cut is indicated by the black line.

(4A), sucrose led to a significant increase in the mRNA abundance for HMG-CoA synthase, MVK and the FASN. The over-expression was prevented by cell pre-incubation with invertase. Surprisingly, neither the expression of LDLr nor SCD-1 was increased at this point. Suspecting a kinetics difference in the time course of expression for these genes, we therefore examined the expression of these two genes in $143 \mathrm{~B}$ cells incubated with $100 \mathrm{mM}$ sucrose for increasing periods of time. As shown in Fig. (4B), the sucrose treatment led to a marked but transient increase in the mRNA relative abundances of LDLr and SCD-1 between $8 \mathrm{~h}$ and $16 \mathrm{~h}$ of incubation. These sucrose-induced over-expressions were also observed at the protein level (Fig. 5). Indeed, the 
A

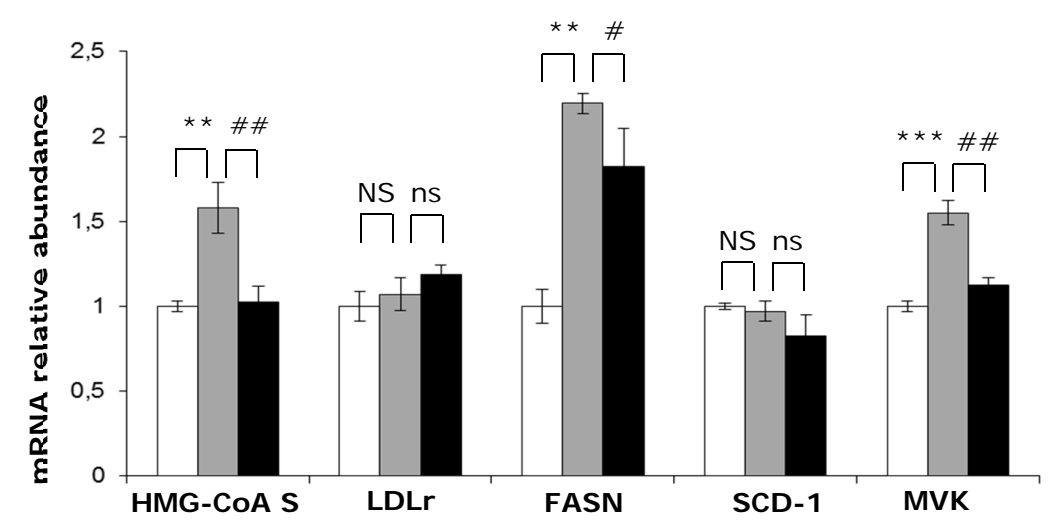

B
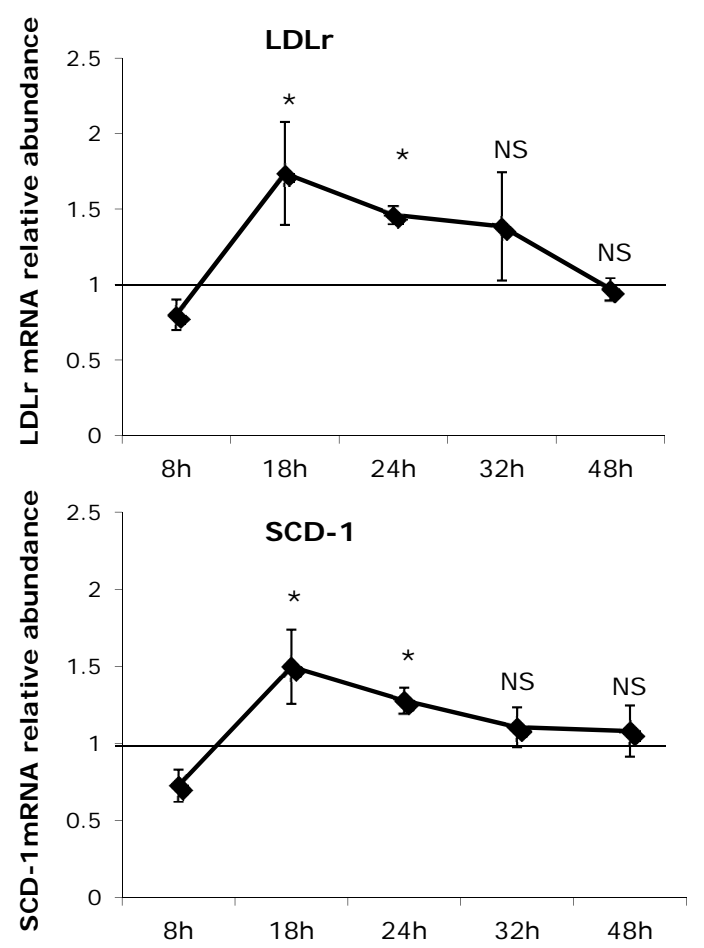

Fig. (4). Effects of a lysosomal sucrose storage on the expression of some well-known SREBPs target genes. (A) 143B cells were incubated for $48 \mathrm{~h}$ with (grey and black columns) or without (white columns) $100 \mathrm{mM}$ sucrose. Cells first pre-incubated for $16 \mathrm{~h}$ with 100 $\mu \mathrm{g} / \mathrm{ml}$ invertase were used as controls (black columns). Total RNA was extracted, reverse transcribed and amplified by real time RT-qPCR in the presence of the HMG-CoA synthase, FASN, LDLr, MVK, or SCD-1 primers and SYBR green. Aldolase was used as reference gene for data normalization. Results are expressed in fold induction of the mRNA abundance found in CTL cells and represent means \pm SD $(n=3)$ ***, **: Significantly different from CTL cells with $\mathrm{P}<0.001, \mathrm{P}<0.01$, respectively. \#, \#\#: Significantly different from cells incubated with sucrose with $\mathrm{P}<0.05$ and $\mathrm{P}<0.01$, respectively, as determined by an ANOVA-1 followed by a Dunnett's test. NS, ns: non significantly different from CTL cells or 143B cells incubated with sucrose, respectively. (B) 143B cells were incubated for increasing periods of time with or without $100 \mathrm{mM}$ sucrose. The mRNA relative abundance of LDLr and of SCD-1 was determined as in A. Results are expressed in fold induction of the mRNA abundance found in CTL cells and represent means \pm SD $(n=3) *$ : significantly different from CTL cells with $\mathrm{P}<0.05$ as determined by a Student's t-test. NS: not significantly different from CTL cells.

abundance of the LDLr was increased in 143B cells incubated with sucrose in a time-dependent manner. The abundance of SCD-1 was transiently increased in 143B incubated for $24 \mathrm{~h}$ with sucrose. However, this effect was no longer observed after 48 and $72 \mathrm{~h}$ of treatment. Finally, the abundance of the MVK was modestly increased after $72 \mathrm{~h}$ of treatment. These increased abundances were no longer observed in $143 \mathrm{~B}$ cells pre-incubated for $16 \mathrm{~h}$ with 100 $\mu \mathrm{g} / \mathrm{ml}$ of invertase (Fig. 5).

\subsection{The Lipid Biosynthesis is Increased in 143B Cells Incubated with Sucrose}

Having seen that the expression of several actors of lipid metabolism was increased when lysosomes are allowed to store sucrose, we wanted to compare the global synthesis of lipids in control and sucrose-treated cells. To this aim, cells were incubated for $24 \mathrm{~h}$ with $2 \mu \mathrm{Ci}\left[{ }^{3} \mathrm{H}\right]$-acetate and radioactivity associated with lipids was measured [28]. Fig. 


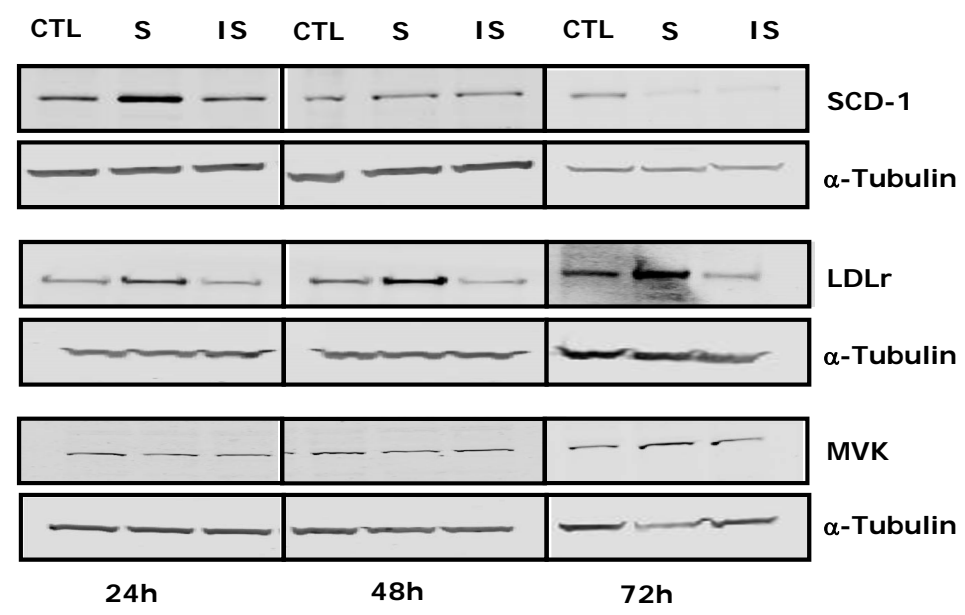

Fig. (5). Effects of a lysosomal sucrose storage on the abundance of the SCD-1, the LDLr and the MVK. The abundance of SCD-1, LDLr and MVK was analyzed by Western Blotting performed on $40 \mu \mathrm{g}$ of proteins from clear lysates prepared from 143B cells incubated for the indicated time with (S), (IS) or without (CTL) $100 \mathrm{mM}$ sucrose. In (IS), cells were pre-incubated for $16 \mathrm{~h} \mathrm{with} 100 \mu \mathrm{g} / \mathrm{ml}$ invertase. Equal protein loading was controlled by the immuno-detection of the $\alpha$-tubulin.

(6) shows that the incorporation of radiolabelled acetate was significantly increased in cells incubated for $48 \mathrm{~h}$ (but not 24 h) with $100 \mathrm{mM}$ sucrose and that this effect could be prevented by invertase.

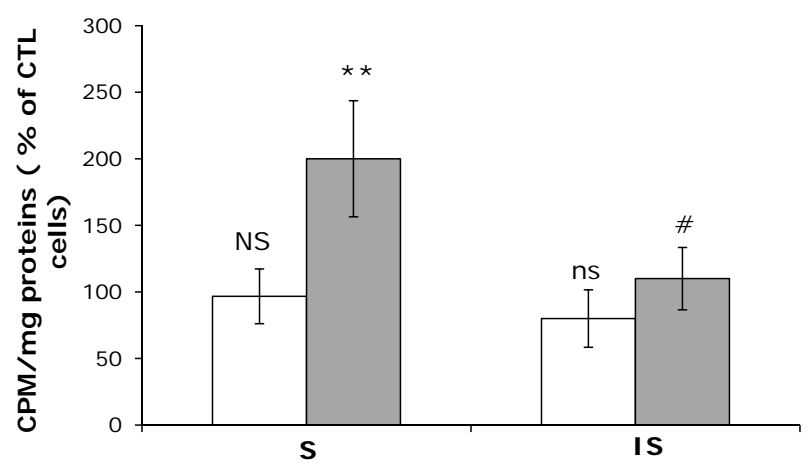

Fig. (6). Effect of a lysosomal sucrose storage on the $\left[{ }^{3} \mathrm{H}\right]-$ acetate incorporation. 143B cells were incubated for $24 \mathrm{~h}$ (white columns) or $48 \mathrm{~h}$ (grey columns) with (S) (IS) or without (CTL) $100 \mathrm{mM}$ sucrose. In (IS), cells were pre-incubated for $16 \mathrm{~h}$ with 100 $\mu \mathrm{g} / \mathrm{ml}$ invertase. $24 \mathrm{~h}$ before the end of the incubation with sucrose, 11.6 $\mu \mathrm{Ci}$ of $\left[{ }^{3} \mathrm{H}\right]$-acetate was added in the culture medium. Following this incubation, cells were scrapped, rinsed with PBS and lipids were extracted using the classical Bligh and Dyer's method as described in the Material and Methods section. Incorporation of $\left[{ }^{3} \mathrm{H}\right]$-acetate into lipids was quantified after lipid extraction (CPM) and normalized for total protein content. Results are expressed in percentages of the $\left[{ }^{3} \mathrm{H}\right]$-acetate in CTL cells as means \pm SD $(n=4)$ **: Significantly different from CTL cells with $\mathrm{P}<0.05$ as determined by a Student's t-test. \#: Significantly different from 143B cells incubated for $48 \mathrm{~h}$ with sucrose with $\mathrm{P}<0.05$. NS, ns: not significantly different from CTL cells and 143B cells incubated for $24 \mathrm{~h}$ with sucrose, respectively.

3.6. SREBP-2 is Responsible for the Increase in the Expression of the HMG-CoA Synthase and Mevalonate Kinase

In order to identify which isoform(s) of SREBPs is/are responsible for the observed increase in the expression of
HMG-CoA synthase and MVK in response to sucrose, we analyzed the expression of genes encoding these two enzymes in cells incubated for $48 \mathrm{~h}$ with $100 \mathrm{mM}$ sucrose and after the silencing of the expression of SREBP-1 or SREBP-2 isoforms using RNA interference. Real time RT-qPCR revealed an important decrease in the SREBP-1 and 2 transcripts $24 \mathrm{~h}$ after the transfection with siRNA (results not shown). Western Blot analysis confirmed these results, since $24 \mathrm{~h}$ after the transfection with the siRNA against one or the other SREBP isoform, the level of SREBP-1 and 2 was greatly reduced and barely detectable in our conditions (Fig. 7A). It should be noticed that silencing the expression of one isoform had no effect on the abundance of the other one, demonstrating that there is no cross-reactivity between the siRNA used. In addition, the SREBP-1 had no impact on the basal expression level of the HMG-CoA synthase and the MVK, and did not prevent the sucrose mediated overexpression of these genes. By contrast, the silencing of SREBP-2 not only decreased the relative abundance of the transcripts coding for these two enzymes at the basal state but it also prevented their increase in response to sucrose, suggesting that SREBP-2, but not SREBP-1a, is involved in the up-regulation of these genes in 143B cells allowed to store sucrose in their lysosomes (Fig. 7B, C).

\subsection{SREBP-2 is Not Involved in the Increase in the Expression of LC3 in 143B Cells Incubated with Sucrose}

Recently, several studies demonstrated that the SREBPs play essential roles in various physiological processes including the innate immune response, apoptosis or autophagy [9]. Seo and colleagues showed that upon cholesterol depletion, SREBP-2 could transactivate the promoters of some autophagic genes such as the gene encoding the protein microtubule-associated protein 1-light chain 3 beta (MAP1-LC3beta/LC3), an essential component of the autophagosome formation [32]. Interestingly, cholesterol depletion has been shown to induce autophagy in human skin fibroblasts [35]. Based on these premises, we decided to analyze the putative role of the transcription factor SREBP-2 on the expression of LC3, when 143B cells 
A

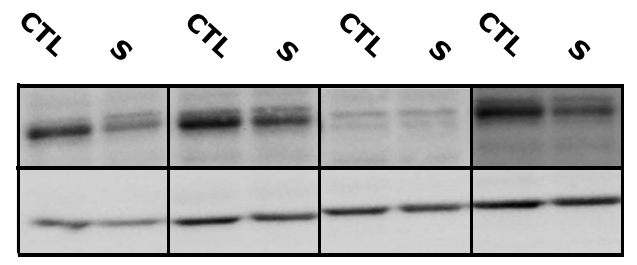

SREBP1

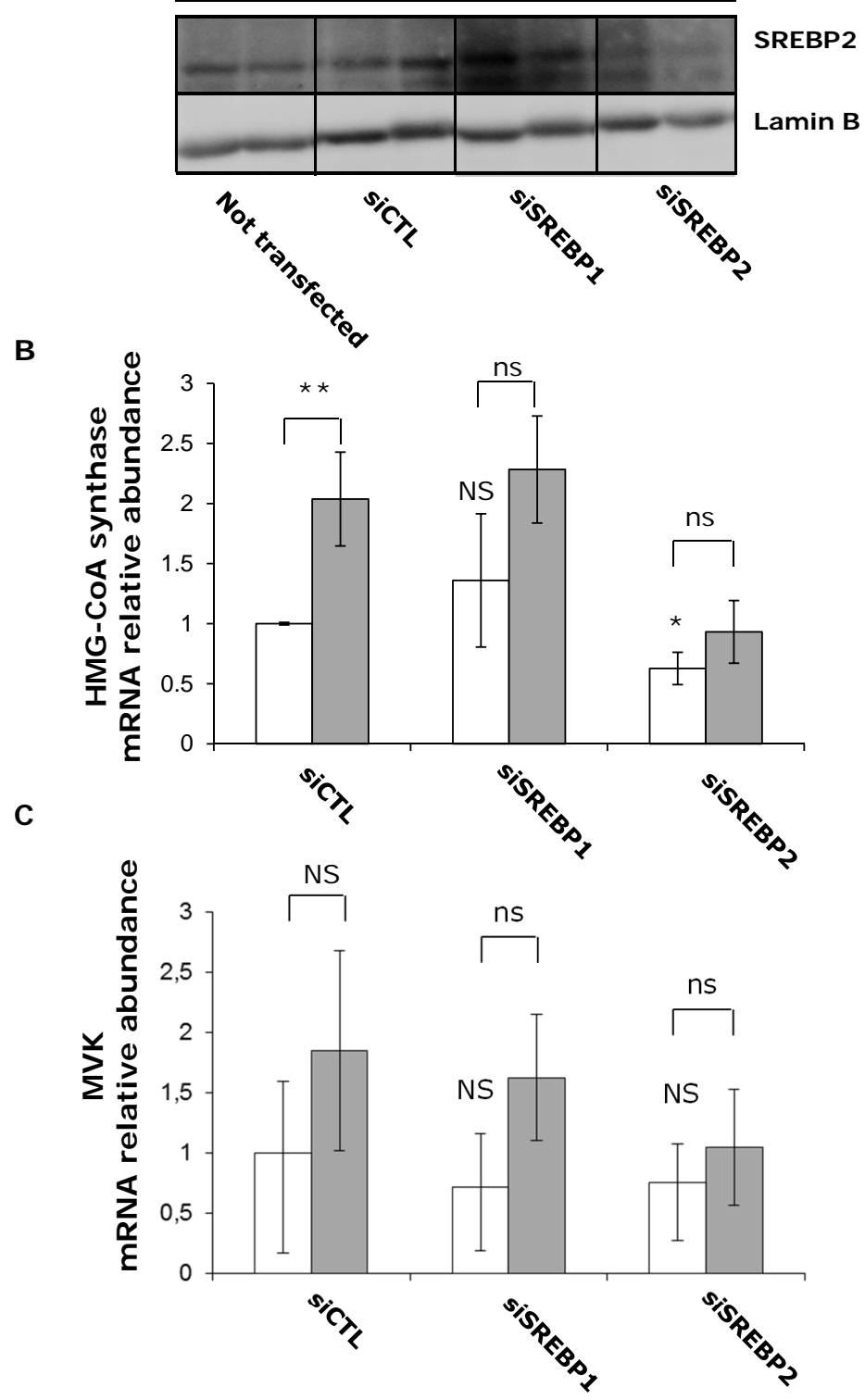

Lamin B

Fig. (7). Effects of a depletion of SREBP-1 or SREBP-2 on the expression of genes coding for the MVK and the HMG-CoA synthase. (A) Efficiency of siRNA-mediated knock-down for SREBP-1 or SREBP-2. The abundance of SREBP-1 or SREBP-2 was analyzed by Western Blotting performed on $40 \mu \mathrm{g}$ of proteins from clear lysates prepared from 143B cells incubated for 48h with [(IS) and (S)] or without $100 \mathrm{mM}$ sucrose. In (IS), cells were first pre-incubated for $16 \mathrm{~h}$ with $100 \mu \mathrm{g} / \mathrm{ml}$ invertase. During the last $24 \mathrm{~h}$, cells were transfected with a pool of four specific siRNAs targeting SREBP-1 (siSREBP-1), SREBP-2 (siSREBP-2) or with a control pool siRNA (siCTL). Equal protein loading was controlled by the immuno-detection of lamin B. For a clearer presentation, two nonessential conditions in which cells have been incubated with invertase alone or with sucrose and invertase have been sliced from the original blot. Bands cut are indicated by the black lines. The expression of the MVK (B) and the HMG-CoA synthase (C) was analyzed in 143B cells incubated for 48h with $100 \mathrm{mM}$ sucrose or not (grey columns and white columns, respectively) and transfected either with a control siRNA (siCTL) or with a pool of four specific siRNA targeting SREBP-1 (siSREBP-1) or SREBP-2 (siSREBP-2). Total RNA was extracted, reverse transcribed and amplified by real time RT-qPCR in the presence of MVK (B) or the HMG-CoA synthase (C) primers and SYBR green. Aldolase was used as a reference gene for data normalization. Results are expressed in fold change of the mRNA abundance found in CTL cells as means $\pm \operatorname{SD}(\mathrm{n}=3) * * *$ : significantly different from CTL cells incubated with the siCTL with $\mathrm{P}<0.05$ and $\mathrm{P}<0.01$, respectively as determined by a Student's t-test. NS, ns: not significantly different from CTL cells incubated with the siCTL or 143B cells incubated with the siSREBP, respectively. 
A

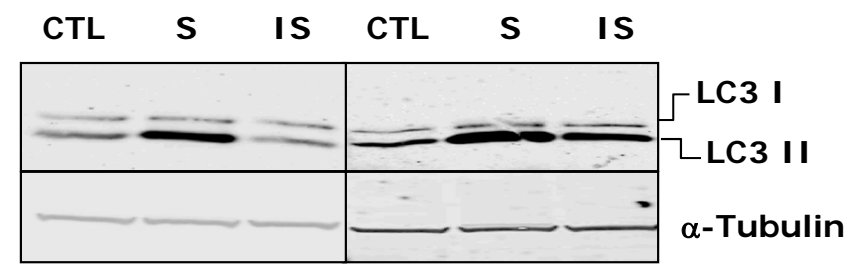

$24 \mathrm{~h} \quad 48 \mathrm{~h}$

B
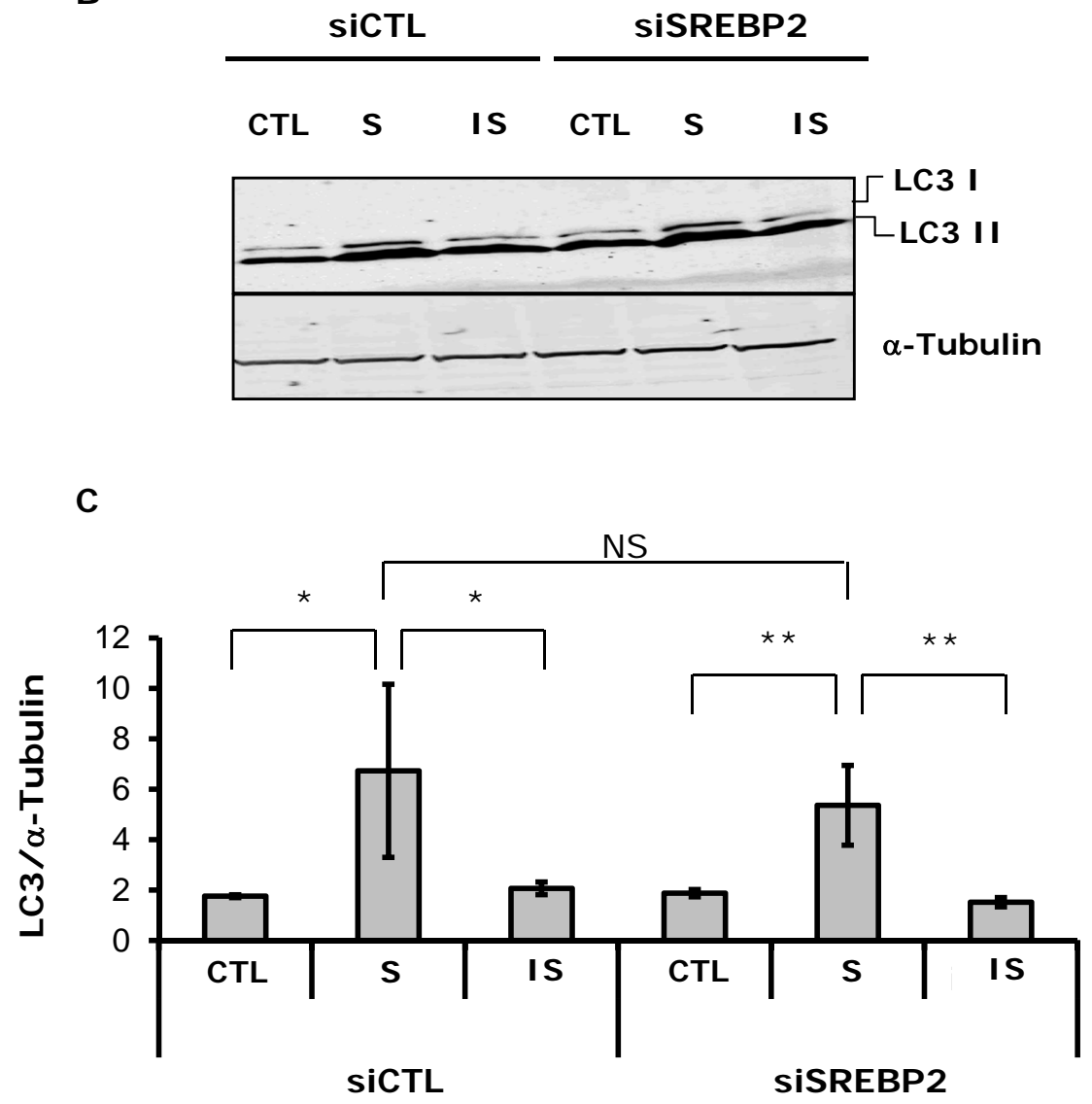

Fig. (8). Effect of a SREBP-2 silencing on the abundance of LC3. (A) The abundance of LC-3 was analyzed by Western Blotting performed on $20 \mu \mathrm{g}$ of proteins from clear cell lysates prepared from 143B cells incubated for the indicated time with (S), (IS) or without (CTL) $100 \mathrm{mM}$ sucrose. In (IS), cells were pre-incubated for $16 \mathrm{~h}$ with $100 \mu \mathrm{g} / \mathrm{ml}$ invertase. Equal protein loading was controlled by the immuno-detection of the $\alpha$-tubulin. (B) The abundance of LC3 was analyzed by Western Blotting performed on $20 \mu \mathrm{g}$ of clear lysates prepared from 143B cells incubated for $48 \mathrm{~h}$ with (S) or without (CTL) $100 \mathrm{mM}$ sucrose and transfected either with a control siRNA (siCTL) or with a pool of four specific siRNA targeting SREBP-2 (siSREBP-2) (representative blot of 3 experiments). Equal protein loading was controlled by the immuno-detection of the $\alpha$-tubulin. (C) Quantification of the Western Blot presented in B. Results are calculated as fluorescence intensity normalized for $\alpha$-tubulin and expressed as means \pm SD $(n=3)$. **, Significantly different from $143 \mathrm{~B}$ cells loaded with sucrose with $\mathrm{P}<0.01$ and $\mathrm{P}<0.05$, respectively as determined by a Student's t-test. NS: not significantly different from $143 \mathrm{~B}$ cells loaded with sucrose and incubated with the siCTL.

are allowed to store sucrose in their lysosomal compartment. As seen in Fig. (8A), sucrose led to a marked increase in the abundance of LC3-I/II which could be prevented by invertase. However, the siRNA-mediated SREBP-2 silencing could not prevent the over-expression of LC3, suggesting that this transcription factor is not directly responsible for the increased abundance of LC3 observed in sucrose-treated cells (Fig 8B, C). 


\section{DISCUSSION}

We show that an experimentally induced lysosomal storage consisting in the accumulation of sucrose in lysosomes triggers the activation of SREBP-2, its translocation to the nucleus, the up-regulation of genes encoding lipogenic proteins and an increased synthesis of lipids.

Accumulation of lipids (and most particularly cholesterol) inside the endo-lysosomal system has been described in a wide range of LSDs including the NiemannPick Disease C (NPC) but also in GM1 and GM2 gangliosidosis, multiple mucopolysaccharidosis, $\alpha$ mannosidosis, LINCL (CLN6 form) or mucolipidosis 4 [29$31,36]$. So far, the molecular mechanisms underlying these defects in the cholesterol trafficking in these LSDs remain elusive. However, according to the "cholesterol-trapping hypothesis" it would result from its tight association with other lipids in late endosome lipid rafts [37]. This hypothesis is supported by the work of Thomas and colleagues which showed that the cholesterol accumulation in NPC1 skin fibroblasts was partially dependent on the inhibition of the activity of the acid sphingomyelinase (SMase) [38]. Increasing the SMase activity in NPC1 deficient cells also leads to a decrease in cholesterol sequestration, suggesting, that the sphingomyelin accumulation could affect the cholesterol traffic inside the endo-lysosomal system [39].

Interestingly, this impaired cholesterol escape from the endo-lysosomal system to the endoplasmic reticulum in NPC-deficient cells has been described to cause an upregulation of cholesterol synthesis and of the LDLr expression, suggesting that the storage has a major effect on the cellular lipid homeostasis [40-42]. Our results show that the lysosomal storage of sucrose induces a modification of the intracellular distribution of non-esterified cholesterol. The more punctuated labelling pattern observed in sucrosetreated cells suggests a defect in cholesterol egress out of the lysosomes and consequently an impaired redistribution of cholesterol to the other intracellular compartments, ER in particular. It can be therefore hypothesized that as in NPC models, the activity of the transcription factors SREBPs is increased due to insufficient lipoprotein-derived cholesterol being able to reach the cholesterol homeostatic pool [43]. SREBP-2 would thus, in turn, activate the expression of some of its target genes including HMG-CoA synthase and mevalonate kinase, resulting, in fine, in an increase in lipids synthesis as determined by $\left[{ }^{3} \mathrm{H}\right]$-acetate incorporation. An increase in the expression of genes involved in cholesterol biosynthesis and fatty acid metabolism was previously reported in a sucrose-induced storage model [44]. Unfortunately, the experimental design of this interesting precursor study did not include the invertase control required to avoid the possible confounding effects of the high sucrose concentration present in the cell culture medium.

Previous studies performed using mice overexpressing one particular SREBP isoform suggested that the two proteins expressed from the $S R E B F 1$ gene, SREBP-1a and SREBP-1c, preferentially target genes of fatty acid metabolism whereas the singular SREBF2 encoded protein preferentially activates genes of cholesterol metabolism [1113]. However, Amemiya-Kudo and colleagues showed, using luciferase-reporter gene assays in HepG2 cells that cholesterogenic genes containing classic sterol response elements (SREs) in their promoters are strongly and efficiently activated by both SREBP-1a and SREBP-2 suggesting that these isoforms could have overlapping functions [45]. Our siRNA interference experiments indicate that the SREBP-2 isoform is the main regulator of mevalonate kinase and $\mathrm{HMG}-\mathrm{CoA}$ synthase expression in 143B cells incubated for $48 \mathrm{~h}$ with $100 \mathrm{mM}$ sucrose.

Besides the proteolytic activation of SREBPs triggered by selective starvation of cholesterol [40], one cannot exclude that other stimuli, not related to the intracellular distribution of free cholesterol could be involved. For example, an increase in SREBP processing and activation has been described as occurring in response to the activation of the unfolded protein response, shear stress and phagocytosis [46-48]. The storage of sucrose has been shown to affect the intracellular trafficking to and from lysosomes, leading to the accumulation of endo-lysosomal "hybrid organelles" $[19,20]$ as well with a perturbation in the maturation of several lysosomal hydrolases [21, 22]. The accumulation of cholesterol inside the lysosomes has been shown to alter the activity of several Rab GTPases (including Rab7, Rab4, Rab11 or Rab9) that are essential to the vesicular trafficking inside the endo-lysosomal system, and also to induce the sequestration of the SNARE proteins VAMP7, Vti1b and syntaxin 7 leading, in fine, to abnormal membrane trafficking along the endosomal system and perturbation of the endosome and lysosome motility [7, 4951]. The altered endo-lysosomal trafficking in cells dealing with a lysosomal storage disorder might signal a "need for lysosomes" triggering a cellular response leading to the coordinated synthesis of membrane and increased lysosomal biogenesis. Interestingly SREBPs have been identified as key regulators of membrane biogenesis in response to the stimulation of phagocytosis, which might signal a requirement for membrane synthesis in order to accommodate the sequestration of membranes in phagolysosomes [48]. The storage of sucrose has been shown to lead to some increase in lysosomal biogenesis [17]. The transcription factor EB (TFEB), a member of the microphthalmia-transcription factor E MiT/TFE subfamily of bHLH transcription factors, was recently described as being a master regulator of lysosomal biogenesis [52]. TFEB activity is activated in response to conditions known to stimulate the accumulation of lysosomes such as in HeLa cells incubated with sucrose but also in embryonic fibroblasts from mouse models for the mucopolysaccharidosis II and IIIA and the Multiple Sulfatase Deficiency [52].

It has been recently shown that SREBP-2 could transactivate the promoter of the gene encoding LC3 (an essential component of the autophagosome formation) in response to cholesterol depletion [32]. Moreover, the SREBP-2 activation during lipid activation was essential to the autophagosome formation and lipid droplet association with LC3 [32]. Knowing that an activation of the autophagic machinery has also been described in several lysosomal storage models $[53,54]$ and that the increase in the autophagic activity observed in the Purkinje cells of the brain of $\mathrm{NPC}^{-/-}$mice was associated with a co-localisation of the LC3+ granules with the cholesterol clusters [53], we were interested to know whether this transcription factor 
could play a role or not in the activation of the autophagy in our experimental model. Our results clearly indicate that even if the expression of LC3 is increased upon lysosomal dysfunction, SREBP-2 is not involved. The involvement of TFEB in the regulation of the expression of some key genes of the macroautophagy such as Beclin 1 and $U V$ radiation resistance associated gene (UVRAG), two proteins that are essential to the autophagosome formation [55], makes this transcription factor a likely candidate for the observed effect of sucrose on the autophagic machinery.

Today, even if the relevance of the sucrosome model in the study of the effects of a lysosomal storage is widely accepted, the question is to know whether this model is a good model to study the molecular mechanisms by which the lysosomal storage triggers broader cellular dysfunctions is still unclear. Our results confirm that the sucrosome model is relevant for the study of the effects of a lysosome vacuolization on the biogenesis of this organelle. This experimental model presents some assets such as its perfect reversibility when cells are pre-incubated with the invertase and the possibility to study the putative transitory molecular events occurring at the early onset of the lysosomal overload.

\section{ABBREVIATIONS}

\begin{tabular}{|c|c|}
\hline FASN & $=$ Fatty acid synthase \\
\hline HMG-CoA synthase & $\begin{aligned}= & 3 \text {-hydroxy-3-methylglutaryl- } \\
& \text { Coenzyme A synthase }\end{aligned}$ \\
\hline LDLr & $=$ Low density lipoprotein receptor \\
\hline LSDs & $=$ Lysosomal storage diseases \\
\hline MAP1-LC3beta/LC3 & $\begin{aligned}= & \text { Microtubule-associated protein } 1- \\
& \text { light chain } 3 \text { beta }\end{aligned}$ \\
\hline MVK & $=$ Mevalonate kinase \\
\hline SCD-1/2 & $=$ Stearoyl-CoA desaturase $1 / 2$ \\
\hline SREBPs & $\begin{aligned}= & \text { Sterol Regulatory Element Binding } \\
& \text { Proteins }\end{aligned}$ \\
\hline
\end{tabular}

\section{CONFLICT OF INTEREST}

The authors confirm that this article content has no conflict of interest.

\section{ACKNOWLEDGEMENTS}

Guillaume Van Beersel is a Research Fellow of the "Fonds National de la Recherche Scientifique" (FSR-FNRS; Brussels, Belgium). This work was supported by the Action de Recherche Concertée-Fédération Wallonie-Bruxelles [Grant number ARC\#326] and the Fonds National de la Recherche Scientifique [Grant number: 2.4650.06]. The authors acknowledge the initial contribution of Sophie Goblet to the study.

\section{REFERENCES}

[1] Walkley SU, Vanier MT. Secondary lipid accumulation in lysosomal disease. Biochim Biophys Acta 2009; 1793: 726-36.

[2] Walkley SU. Pathogenic cascades in lysosomal disease-Why so complex?. J Inherit Metab Dis 2009; 32: 181-9.

[3] -Platt FM, -Boland B, van der Spoel AC. The cell biology of disease: Lysosomal storage disorders: The cellular impact of lysosomal dysfunction. J Cell Biol 2012; 199: 723-34.
[4] Lamanna WC, Lawrence R, Sarrazin S, Esko JD. Secondary storage of dermatan sulfate in Sanfilippo disease. J Biol Chem 2011; 286: 6955-62.

[5] Zhang Z, Lee YC, Kim SJ, et al. Palmitoyl-protein thioesterase-1 deficiency mediates the activation of the unfolded protein response and neuronal apoptosis in INCL. Hum Mol Genet 2006; 15: 337 46.

[6] Ginzburg L, Futerman AH. Defective calcium homeostasis in the cerebellum in a mouse model of Niemann-Pick A disease, $\mathbf{J}$ Neurochem 2005; 95: 1619-28.

[7] Fraldi A, Annunziata F, Lombardi A, et al. Lysosomal fusion and SNARE function are impaired by cholesterol accumulation in lysosomal storage disorders. EMBO J 2010; 29: 3607-20.

[8] Vazquez MC, Balboa E, Alvarez AR, Zanlungo S. Oxidative stress: a pathogenic mechanism for Niemann-Pick type $\mathrm{C}$ disease. Oxid Med Cell Longev 2012; 2012: 205713.

[9] Jeon TI, Osborne TF. SREBPs: metabolic integrators in physiology and metabolism, Trends in endocrinology and metabolism. Trends Endorinol Metab 2012; 23: 65-72.

[10] Hua X, Wu J, Goldstein JL, Brown MS, Hobbs HH. Structure of the human gene encoding sterol regulatory element binding protein-1 (SREBF1) and localization of SREBF1 and SREBF2 to chromosomes 17p11.2 and 22q13. Genomics 1995; 25: 667-73.

[11] Sakakura Y, Shimano H, Sone H, et al. Sterol regulatory elementbinding proteins induce an entire pathway of cholesterol synthesis. Biochem Biophys Res Commun 2001; 286: 176-83.

[12] Horton JD, Shimomura I, Brown MS, Hammer RE, Goldstein JL Shimano H. Activation of cholesterol synthesis in preference to fatty acid synthesis in liver and adipose tissue of transgenic mice overproducing sterol regulatory element-binding protein-2. J Clin Invest 1998; 101: 2331-9.

[13] Shimomura I, Shimano H, Korn BS, Bashmakov Y, Horton JD. Nuclear sterol regulatory element-binding proteins activate genes responsible for the entire program of unsaturated fatty acid biosynthesis in transgenic mouse liver. J Biol Chem 1998; 273: 35299-306.

[14] Jennings JJ, Zhu JH, Rbaibi Y, Luo X, Chu CT, Kiselyov K. Mitochondrial aberrations in mucolipidosis Type IV. J Biol Chem 2006; 281: 39041-50.

[15] Otomo T, Higaki K, Nanba E, Ozono K, Sakai N. Inhibition of autophagosome formation restores mitochondrial function in mucolipidosis II and III skin fibroblasts. Mol Genet Metab 2009; 98: 393-9.

[16] Cohn ZA, Ehrenreich BA. The uptake, storage, and intracellular hydrolysis of carbohydrates by macrophages. J Exp Med 1969; 129: 201-25

[17] Karageorgos LE, Isaac EL, Brooks DA, et al. Lysosomal biogenesis in lysosomal storage disorders. Exp Cell Res 1997; 234: 85-97.

[18] Ferris AL, Brown JC, Park RD, Storrie B. Chinese hamster ovary cell lysosomes rapidly exchange contents. J Cell Biol 1987; 105: 2703-12.

[19] Luzio JP, Poupon V, Lindsay MR, Mullock BM, Piper RC, Pryor PR. Membrane dynamics and the biogenesis of lysosomes. Mol Membr Biol 2003; 20: 141-54.

[20] Mullock BM, Bright NA, Fearon CW, Gray SR, Luzio JP. Fusion of lysosomes with late endosomes produces a hybrid organelle of intermediate density and is NSF dependent. J Cell Biol 1998; 140: 591-601.

[21] Schmid JA, Mach L, Paschke E, Glossl J. Accumulation of sialic acid in endocytic compartments interferes with the formation of mature lysosomes. Impaired proteolytic processing of cathepsin B in fibroblasts of patients with lysosomal sialic acid storage disease. J Biol Chem 1999; 274: 19063-71.

[22] Hamer I, Jadot M. Endolysosomal transport of newly-synthesized cathepsin D in a sucrose model of lysosomal storage. Exp Cell Res 2005; 309: 284-95.

[23] Hamer I, Delaive E, Dieu M, et al. Up-regulation of cathepsin B expression and enhanced secretion in mitochondrial DNA-depleted osteosarcoma cells. Biol Cell 2009; 101: 31-41.

[24] Peters TJ, Muller M, Duve CD. Lysosomes of the arterial wall. I. Isolation and subcellular fractionation of cells from normal rabbit aorta. J Exp Med 1972; 136: 1117-39.

[25] Longueville FD, Atienzar FA, Marcq L, et al., Use of a low-density microarray for studying gene expression patterns induced by 
hepatotoxicants on primary cultures of rat hepatocytes. Toxicol Sci 2003; 75: 378-92.

[26] Beersel GV, Tihon E, Demine S, Hamer I, Jadot M, Arnould T. Different molecular mechanisms involved in spontaneous and oxidative stress-induced mitochondrial fragmentation in TriPeptidyl Peptidase-1 (TPP-1) deficient fibroblasts. Biosci Rep 2012 [Epub head of print].

[27] Rommelaere G, Michel S, Mercy L, et al. Hypersensitivity of mtDNA-depleted cells to staurosporine-induced apoptosis: roles of Bcl-2 downregulation and cathepsin B. Am J Physiol Cell Physiol 2011; 300: C1090-106.

[28] Bligh EG, Dyer WJ. A rapid method of total lipid extraction and purification. Can J Biochem Physiol 1959; 37: 911-7.

[29] Teixeira CA, Lin S, Mangas M, et al. Gene expression profiling in vLINCL CLN6-deficient fibroblasts: Insights into pathobiology. Biochim Biophys Acta 2006; 1762: 637-46.

[30] McGlynn R, Dobrenis K, Walkley SU. Differential subcellular localization of cholesterol, gangliosides, and glycosaminoglycans in murine models of mucopolysaccharide storage disorders. J Comp Neurol 2004; 480: 415-26.

[31] Zervas M, Dobrenis K, Walkley SU. Neurons in Niemann-Pick disease type $\mathrm{C}$ accumulate gangliosides as well as unesterified cholesterol and undergo dendritic and axonal alterations. J Neuropathol Exp Neurol 2001; 60: 49-64.

[32] Seo YK, Jeon TI, Chong HK, Biesinger J, Xie X, Osborne TF. Genome-wide localization of SREBP-2 in hepatic chromatin predicts a role in autophagy. Cell Metab 2011; 13: 367-75.

[33] Hirano Y, Yoshida M, Shimizu M, Sato R. Direct demonstration of rapid degradation of nuclear sterol regulatory element-binding proteins by the ubiquitin-proteasome pathway. J Biol Chem 2001; 276: 36431-7.

[34] Weber LW, Boll M, Stampfl A. Maintaining cholesterol homeostasis: sterol regulatory element-binding proteins. World $\mathbf{J}$ Gastroenterol 2004; 10: 3081-7.

[35] Cheng J, Ohsaki Y, Tauchi-Sato K, Fujita A, Fujimoto T. Cholesterol depletion induces autophagy. Biochem Biophys Res Commun 2006; 351: 246-52.

[36] Damme M, Stroobants S, Walkley SU, et al. Cerebellar alterations and gait defects as therapeutic outcome measures for enzyme replacement therapy in alpha-mannosidosis. J Neuropathol Exp Neurol 2011; 70: 83-94.

[37] Simons K, Gruenberg J. Jamming the endosomal system: lipid rafts and lysosomal storage diseases, Trends Cell Biol 2000; 10: 459-62.

[38] Thomas GH, Tuck-Muller CM, Miller CS, Reynolds LW. Correction of sphingomyelinase deficiency in Niemann-Pick type C fibroblasts by removal of lipoprotein fraction from culture media. J Inherit Metabol Dis 1989; 12: 139-51.

[39] Devlin C, Pipalia NH, Liao X, Schuchman EH, Maxfield FR, Tabas I. Improvement in lipid and protein trafficking in NiemannPick $\mathrm{C} 1$ cells by correction of a secondary enzyme defect. Traffic 2010; 11: 601-15.
[40] Liscum L, Faust JR. Low density lipoprotein (LDL)-mediated suppression of cholesterol synthesis and LDL uptake is defective in Niemann-Pick type C fibroblasts. J Biol Chem 1987; 262: 17002-8.

[41] Puri V, Jefferson JR, Singh RD, Wheatley CL, Marks DL, Pagano RE. Sphingolipid storage induces accumulation of intracellular cholesterol by stimulating SREBP-1 cleavage. J Biol Chem 2003; 278: 20961-70.

[42] Kulinski A, Vance JE. Lipid homeostasis and lipoprotein secretion in Niemann-Pick C1-deficient hepatocytes. J Biol Chem 2007; 282: 1627-37.

[43] Kristiana I, Yang H, Brown AJ. Different kinetics of cholesterol delivery to components of the cholesterol homeostatic machinery: implications for cholesterol trafficking to the endoplasmic reticulum. Biochim Biophys Acta 2008; 1781: 724-30.

[44] Helip-Wooley A, Thoene JG. Sucrose-induced vacuolation results in increased expression of cholesterol biosynthesis and lysosomal genes. Exp Cell Res 2004; 292: 89-100.

[45] M. Amemiya-Kudo, H. Shimano, A.H. Hasty, et al. Transcriptional activities of nuclear SREBP-1a, -1c, and -2 to different target promoters of lipogenic and cholesterogenic genes. J Lipid Res 2002; 43: 1220-35

[46] Kammoun HL, Chabanon H, Hainault I, et al. GRP78 expression inhibits insulin and ER stress-induced SREBP-1c activation and reduces hepatic steatosis in mice. J Clin Invest 2009; 119: 1201-15.

[47] Liu Y, Chen BP, Lu M, et al. Shear stress activation of SREBP1 in endothelial cells is mediated by integrins. Arterioscler Thromb Vasc Biol 2002; 22: 76-81.

[48] Castoreno AB, Wang Y, Stockinger W, et al. Transcriptional regulation of phagocytosis-induced membrane biogenesis by sterol regulatory element binding proteins. Proc Natl Acad Sci USA 2005; 102: 13129-34.

[49] Choudhury A, Sharma DK, Marks DL, Pagano RE. Elevated endosomal cholesterol levels in Niemann-Pick cells inhibit rab4 and perturb membrane recycling. Mol Biol Cell 2004; 15: 4500-11.

[50] Sobo K, Blanc IL, Luyet PP, et al. Late endosomal cholesterol accumulation leads to impaired intra-endosomal trafficking. PloS ONE 2007; 2: e851.

[51] Walter M, Chen FW, Tamari F, Wang R, Ioannou YA. Endosomal lipid accumulation in NPC1 leads to inhibition of PKC, hypophosphorylation of vimentin and Rab9 entrapment. Biol Cell 2009; 101: 141-52.

[52] Sardiello M, Palmieri M, di Ronza A, et al. A gene network regulating lysosomal biogenesis and function. Science 2009; 325: 473-7.

[53] Ishibashi S, Yamazaki T, Okamoto K. Association of autophagy with cholesterol-accumulated compartments in Niemann-Pick disease type C cells. J Clin Neurosci 2009; 16: 954-9.

[54] Pacheco CD, Kunkel R, Lieberman AP. Autophagy in NiemannPick C disease is dependent upon Beclin-1 and responsive to lipid trafficking defects. Hum Mol Genet 2007; 16: 1495-503.

[55] Settembre C, Di Malta C, Polito VA, et al. TFEB links autophagy to lysosomal biogenesis. Science 2011; 332(6036): 1429-33.

(C) Van Beersel et al.; Licensee Bentham Open.

This is an open access article licensed under the terms of the Creative Commons Attribution Non-Commercial License (http://creativecommons.org/licenses/by$\mathrm{nc} / 3.0 /$ ) which permits unrestricted, non-commercial use, distribution and reproduction in any medium, provided the work is properly cited. 